\title{
Pengaruh Latihan Birthball terhadap Proses Persalinan
}

\author{
Siti Mutoharoh ${ }^{1}$, Eni Indrayani ${ }^{2}$, Kusumastuti ${ }^{3}$ \\ 1. STIKES Muhammadiyah Gombong, email: sitimutoharoh23@gmail.com \\ 2. STIKES Muhammadiyah Gombong, email: ncuz.kusuma26@gmail.com \\ 3. STIKES Muhammadiyah Gombong, emal: eni.indryani29@gmail.com
}

\begin{abstract}
Abstrak. Indikator penilaian status kesehatan salah satunya adalah angka kematian ibu (AKI). Salah satu penyebab kematian ibu adalah partus lama, yaitu partus lebih dari 18 jam. Birth ball adalah salah satu latihan yang bisa diterapkan pada ibu hamil dan bersalin yang dapat berpengaruh terhadap nyeri, lama, dan jenis persalinan. Tujuan penelitian ini adalah untuk mengetahui pengaruh latihan birth ball pada ibu hamil terhadap percepatan servik dan laserasi pada ibu bersalin. Metode penelitian yang digunakan adalah kuasi eksperimental pada dua kelompok, yaitu kelompok perlakuan dan kelompok kontrol dengan masing-masing berjumlah 30 responden. Responden pada penelitian ini adalah ibu hamil fisiologis dengan usia kehamilan lebih dari 34 minggu. Hasil penelian menunjukkan ada pengaruh latihan birth ball terhadap percepatan pembukaan servik ditunjukkan dengan nilai $P$ value 0,002 dan RR 2,09. Sedangkan laserasi perineum tidak dipengaruhi oleh latihan birthball, ditunjukkan dengan $P$ value 3,45. Kesimpulan penelitian adalah terdapat perbedaan signifikan terhadap percepatan pembukaan servik antara kelompok perlakuan yang diberikan latihan birth ball dibandingkan dengan kelompok kontrol, namun tidak ada perbedaan yang signifikan pada kejadian laserasi perineum pada kelompok perlakuan dibandingkan dengan kelompok kontrol.
\end{abstract}

Keywords: birth ball, proses persalinan

\section{The Effect of Birthball Exercises on the Labor Process}

\begin{abstract}
One indicator of health status assessment is the maternal mortality rate (MMR). One cause of maternal death is prolonged labor, which is more than 18 hours. Birth ball is one of the exercises that can be applied to pregnant and childbirth women to influence pain, duration, and type of delivery. The purpose of this study was to determine the effect of birth ball training on pregnant women on cervical acceleration and laceration in maternity. The research method used was quasi-experimental in two groups, namely the treatment group and the control group with 30 respondents each. Respondents in this study were physiologically pregnant women with a gestational age of more than 34 weeks. The results of the study showed that there was an effect of birth ball training on the acceleration of cervical opening as indicated by the $P$ value 0.002 and $R R$ 2.09. While perineal laceration is not influenced by birthball practice, indicated by a $P$ value of 3.45 . The conclusion of the study was that there was a significant difference in the acceleration of cervical opening between the treatment groups given birthball training to the control group, but there was no significant difference in perineal laceration in the control and treatment groups. Keywords: birthball, labor process
\end{abstract}

\section{Pendahuluan}

Angka Kematian Ibu (AKI) merupakan salah satu indikator penilaian status kesehatan. AKI di Indonesia tercatat masih tinggi, yaitu mencapai 359 per 100 ribu kelahiran hidup (SDKI, 2012). Rata-rata kematian ini jauh melonjak dibanding hasil SDKI 2007 yang mencapai 228 per 100 ribu. Penyebab kematian ibu di Indonesia yang terdiri dari perdarahan $(42 \%), \quad$ eklampsi/preeklampsi $\quad(13 \%)$, abortus (11\%), Infeksi (10\%), persalinan lama/persalinan macet $(9 \%)$, penyebab lain $(15 \%)$. 
Terdapat beberapa faktor yang berpengaruh terhadap lama persalinan yaitu usia, paritas, his, keadaan panggul, letak janin, dan besarnya janin. Faktor umur berpengaruh terhadap terjadinya komplikasi pada persalinan seperti kelainan his, atonia uteri, dan plasenta previa. Ibu primitua yang berusia lebih dari 35 tahun memiliki resiko kematian perinatal yang lebih besar. Pada usia tersebut sering ditemukan perineum yang kaku dan tidak elastis sehingga menyebabkan masalah pada saat persalinan terutama pada saat kala II. Jalan lahir yang elastis biasanya tidak memberikan kesulitan pada saat kelahiran kepala bayi (Manuaba, 2010).

Menurut Manuaba (2010) usia sehat dalam reproduksi adalah 20-35 tahun. Usia tersebut lebih aman dan memiliki resiko yang rendah dalam kematian perinatal.

Proses persalinan juga dipengaruhi oleh power, yang terdiri dari his dan kemampuan mengejan dari ibu. Kekuatan mengejan ibu dan his dapat mempercepat pembukaan servik dan mendorong janin untuk keluar (Manuaba, 2010).

Faktor lain yang berpengaruh terhadap lama persalinan adalah keadaan panggul. Kelainan bentuk panggul dapat menghambat proses persalinan. Letak dan presentasi janin adalah bagian penting pada proses persalinan. $98 \%$ persalinan terjadi pada presentasi janin belakang kepala. Persalinan adalah suatu proses kepala janin untuk keluar dari rahim melewati rongga panggul, sehingga diperlukan keseimbangan ukuran antara janin terutama bagian kepala dengan rongga panggul. Apabila terjadi kelainan pada letak, posisi, dan presentasi janin maka akan terjadi kesulitan pada proses persalinan diakibatkan ketidaksesuaian ukuran janin dengan rongga panggul (Manuaba, 2010).
Birth ball adalah salah satu latihan yang bisa diterapkan pada ibu hamil dan bersalin yang dapat berpengaruh terhadap nyeri, lama, dan jenis persalinan Ibu bersalin yang memilih posisi tidak berbaring di tempat tidur pada saat kala 1 fase aktif, terbukti memiliki waktu yang lebih cepat dalam persalinannya (Vaijayantimala dan Judie, 2014).

Penggunaan birth ball selama kehamilan dapat mempersingkat waktu persalinan karena akan merangsang refleks postural dan menjaga otot-otot yang mendukung tulang belakang, serta menjadikan bayi berubah ke posisi yang benar (Aprilia, 2011).

Berdasarkan hasil penelitian Lia Mota, dkk (2011) Latihan birth ball terbukti memberikan efek terhadap waktu persalinan sebesar $17,1 \%$.

\section{Metode}

Penelitian ini merupakan penelitian kuantitatif kuasi eksperimental pada dua kelompok, yaitu kelompok perlakuan dan kelompok kontrol dengan masing-masing berjumlah 30 responden. Analisis data menggunakan chi-square. Responden pada penelitian ini adalah ibu hamil fisiologis dengan usia kehamilan lebih dari 34 minggu. Pada kelompok perlakuan dilakukan latihan birthball sebanyak 4 kali dalam 4 minggu.

\section{Hasil penelitian}

\section{Karakteristik Responden}

Tabel 1. Distribusi frekuensi Karakteritik sresponden

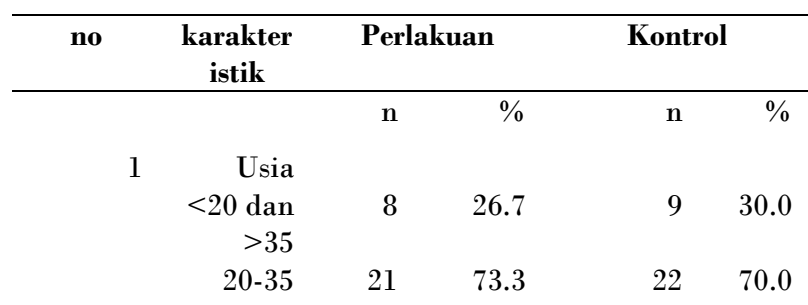


$2 \quad$ Pendidi

$$
\text { kan }
$$

$\begin{array}{lll}\text { SD } & 6 & 20.0\end{array}$

SMP $\quad 13 \quad 43.3$

$\begin{array}{lll}\text { SMA } & 11 \quad 36.7\end{array}$

$\begin{array}{ll}0 & 0.0\end{array}$

$8 \quad 26.7$

$22 \quad 73.3$

$3 \quad$ Pekerja

an

IRT

$27 \quad 90.0$

$4 \quad$ Wirasw

$3 \quad 10.0$

asta

Paritas

$\begin{array}{lllll}\text { Multipa } & 22 & 73.3 & 18 & 60.0\end{array}$

$\begin{array}{rrrrr}\text { ra } & & & & \\ \text { Primapr } & 6 & 20.0 & 12 & 40.0\end{array}$

$\begin{array}{llll}\text { Grande } & 2 & 6.7 & 0\end{array}$

Berdasarkan tabel diatas, sebagian besar responden berusia antara 20-35 tahun baik pada klompok perlakuan (73.3\%) maupun pada kelompok kontrol $(70 \%)$. Sedangkan pendidikan rsponden pada kelompok perlakuan sebagian besar SMP $(43.3 \%)$ dan pada kelompok kontrol sebagian besar SMA (73.3\%). Pekerjaan responden sebagian besar adalah tidak bekerja atau sebagai ibu rumah tangga (IRT) baik pada kelompok perlakuan $(90 \%)$ maupun kelompok kontrol (100\%). Sebagian besar responden pada kelompok kontrol dan perlakuan adalah multipara yaitu $73.3 \%$ pada kelompok perlakuan dan $60 \%$ pada kelompok kontrol.

\section{Percepatan pembukaan servik}

Tabel 2. Percepatan pembukaan servik

\begin{tabular}{|c|c|c|c|c|c|c|}
\hline & \multicolumn{4}{|c|}{$\begin{array}{c}\text { Percepatan } \\
\text { pembukaan servik }\end{array}$} & \multirow[b]{3}{*}{$\begin{array}{c}\mathrm{P} \\
\text { val } \\
\text { ue }\end{array}$} & \multirow[b]{3}{*}{$\begin{array}{l}\mathrm{R} \\
\mathrm{R}\end{array}$} \\
\hline & \multicolumn{2}{|c|}{$\begin{array}{c}>=1 \\
\mathrm{~cm} / \mathrm{jam}\end{array}$} & \multicolumn{2}{|c|}{$\begin{array}{r}<1 \\
\mathrm{~cm} / \mathrm{jam}\end{array}$} & & \\
\hline & $\mathbf{n}$ & $\%$ & $\mathrm{n}$ & $\%$ & & \\
\hline KLP & & & & & & \\
\hline $\begin{array}{r}\text { Perlaku } \\
\text { an }\end{array}$ & 23 & 76.7 & 7 & 23.3 & $\begin{array}{c}0.0 \\
02\end{array}$ & $\begin{array}{c}2.0 \\
9\end{array}$ \\
\hline Kontrol & 11 & 56.7 & 19 & 63.3 & & \\
\hline
\end{tabular}
20-35 tahun. Pada ibu multipara, rahim harus bekerja lebih ekstra di bandingkan pada ibu primipara. Akan tetapi, hal

Berdasarkan Tabel 2. terlihat ada perbedaan yang signifikan terhadap percepatan pembukaan servik selama proses persalinan pada kelompok perlakuan yang diberikan latihan birth ball selama kehamilan dibandingkan dengan kelompok kontrol dibuktikn dengan nilai $p$ value 0.0002 dan RR 2.09.

\section{Laserasi perineum}

Tabel 3. Kejadian laserasi perineum

\begin{tabular}{|c|c|c|c|c|c|c|}
\hline \multicolumn{4}{|c|}{ Laserasi Perinium } & \multirow[b]{3}{*}{$\begin{array}{c}\mathrm{P} \\
\text { val } \\
\text { ue }\end{array}$} & \multirow[b]{3}{*}{ RR } & \multirow[b]{3}{*}{ CI } \\
\hline \multicolumn{2}{|c|}{ Tdk ada } & & ada & & & \\
\hline $\mathbf{n}$ & $\%$ & $\mathbf{n}$ & $\%$ & & & \\
\hline 15 & 50.0 & 15 & 50.0 & 3.4 & 1.6 & -2.62 \\
\hline 8 & 26.7 & 22 & 73.3 & 54 & 1 & 0.98 \\
\hline
\end{tabular}

Berdasarkan tabel 2 terlihat tidak ada perbedaan antara kejadian laserasi perineum pada kelompok perlakuan yang diberikan latihan birth ball selama kehamilan dibandingkan dengan kelompok kontrol yang ditunjukkan dengan nilai $\mathrm{P}$ value 3.454 .

\section{Pembahasan}

Proses persalinan dipengaruhi oleh $3 \mathrm{P}$, yaitu power meliputi kontraksi dan tenaga mengejan ibu, passage meliputi kondisi panggul, servik (dilatasi/pembukaan), dan vagina, dan passanger yaitu bayi dan plasenta (Prawirohardjo, 2009).

CI Umur reproduksi sehat pada ibu hamil adalah 20-35 tahun. Kematian maternal pada ibu hamil dan melahirkan pada usia kurang dari 20 tahun dan lebih dari 35 1.25 - tan meningkat 2-5 kali dibandingkan pada ibu hamil dan melahirkan pada usia 
tersebut dapat diatasi melalui kegiatan aktifitas fisik yang baik pada ibu hamil. Jumlah paritas 2-3 merupakan jumlah yang paling aman pada ibu hamil dan melahirkan. Pengalaman kehamilan dan persalinan yang tidak menyenagkan akan mempengaruhi kehamilan dan persalinan selanjutnya. Pendidikan yang rendah bisanya dikaitkan dengan tingkat kemiskinan, kebodohan, dan tingkat pengetahuan yang rendah. Rendahnya informasi yang diperoleh akan memberikan dampak yang buruk terhadap proses kehamilan dan persalinan. Ibu hamil dan keluarga akan sulit mengenali tanda-tanda bahaya selama kehamilan dan persalinan, sehingga memperbesar resiko terjadinya kematian maternal dan perinatal (Soviaty, 2016.)

Dalam proses persalinan, bola (birth ball) bisa menjadi alat yang penting dan dapat digunakan dalam berbagai posisi. Latihan gerakan dengan menggunakan birth ball dengan cara mengayunkan dan mengayunkan panggul ke depan, belakang, kanan, dan kiri secara perlahan dapat meredakan tekanan dan meningkatkan bidang luas panggul, mendorong turunnya kepala bayi, membantu kontraksi rahim lebih efektif, mempercepat dilatasi servik, dan membantu relaksasi ligamentum pada panggul (Aprilia, 2011).

Birt ball juga dapat memberikan efek positif lain seperti mengurangi rasa sakit saat kontraksi. Pada posisi duduk, memungkinkan suami atau sebagai pendamping persalinan untuk memberikan pijatan lembut pada punggung sehingga memberikan relaksasi pada ibu (Aprilia, 2011).

Birtball juga dapat dilakukan dengan ibu pada posisi berdiri dan bersandar di atas bola, mendorong dan mengayunkan panggul untuk melatih mobilisasi panggul. Bola juga dapat diletakkan di lantai atau tempat tidur, kemudian ibu melakukan posisi berlutut dan membungkuk dsehingga berat badan ibu bertumpu pada bola. Gerakan ibu pada saat mendorong panggul dapat membantu merubah posisi bayi ke posisi yang lebih tepat (belakang kepala) sehingga dapat mempercepat kemajuan persalinan (Aprilia, 2011).

Berbagai keuntungan yang bisa didapatkan pada posisi duduk tegak di atas bola adalah meningkatkan aliran darah ke rahim, plasenta, dan bayi; mengurangi tekanan dan meningkatkan bidang luas panggul; memberikan rasa nyaman pada pergelangan kaki; mendorong turunnya kepala bayi; merelakskan panggul; dan memberikan kenyamanan pada ibu. Menggunakan birth ball dengan posisi jongkok menjadikan perineum meregang secara optimal, sehingga aliran darah ke bayi menjadi lancar. Selain itu, panggul akan menjadi lebih luas sehingga mempercepat turunnya bayi (Aprilia, 2011).

Winny SC, Sze-wing, dan Wan-hon Li (2011) pada penelitiannya menyebutkan bahwa latihan menggunakan birth ball sangat efektif terhadap proses persalinan. Sebagian besar responden yang diberikan latihan birth ball berakhir dengan persalinan spontan.

Vaijayantimala dan Judie (2014) pada penelitiannya menunjukkan bahwa ada perbedaan terhadap lama persalinan pada kelompok kontrol yang dilakukan latihan birt ball dibandingkan dengan kelompok kontrol yang ditunjukkan dengan nilai $p$ value 0.001 . Birthball juga terbukti efektif pada kontraksi rahim yang ditunjukkan dengan nilai $p$ value 0.001 . Birth ball efektif memperngaruhi jenis persalinan. Jumlah persalinan normal melalui vagina lebih banyak terjadi pada Ibu hamil yang melakukan latihan birth ball secara rutin dibandingkan dengan ibu hamil yang tidak melakukan latihan birthball. Hal tersebut dipengaruhi oleh kontraksi uterus yang baik dan lama waktu persalinan. Pada ibu hamil yang tidak melakukan latihan birth 
ball, lebih banyak ibu hamil yang melahirkan secara secsio caesarian.

Latihan birth ball yang dilakukan selama persalinan mampu mengurangi nyeri pada persalinan, memberikan pengalaman yang positif (menyenangkan) selama persalinan. Birth ball dapat digunakan sebagai metode yang simple, dan merupakan metode non farmakologi yang baik untuk dalam persalinan Vaijayantimala dan Judie (2014) .

\section{Simpulan}

Terdapat perbedaan signifikan percepatan pembukaan servik antara kelompok perlakuan yang diberikan latihan birth ball selama hamil dibandingkan dengan kelompok kontrol, namun tidak ada perbedaan yang signifikan pada kejadian laserasi perineum pada kelompok perlakuan dibandingkan dengan kelompok kontrol.

\section{Ucapan Terimakasih}

Terimakasih kami sampaikan kepada RISTEKDIKTI yang telah mendanai penelitian hibah PDP ini, STIKES Muhammadiyah Gombong yang telah memberikan dukungan secara moril dan materiil, serta pihak puskesmas Buluspesantren 1 dan Adimulyo yang bekerjasama untuk menjadi bagian dalam penelitian ini.

\section{Daftar Pustaka}

Aprilia, Yessie, Gentle Birth Melahirkan

Nyaman Tanpa Rasa Sakit. Jakarta:

Gramedia Widiasarana Indonesia,

2011.

Manuaba. Ilmu Kebidanan, Penyakit

kandungan, dan KB. Jakarta: EGC. 2010
Lia Mota . Using the Swiss ball in labor. Acta Paul Enferm2011;24(5):656-62. 2011

Prawiroharjo, Ilmu Kebidanan. Jakarta: Bina Pustaka, 2009.

Soviaty. Faktor-faktor yang berhubungan dengan lama persalinan di RSUD 45 Kuningan Jawa Barat tahun 2015. Jurnal Bidan "midwive Journal" volume 2 No. 1 Januari 2016.

Survei Demografi dan Kesehatan Indonesia 2012. BPS: 2013.

Vaijayantimala dan Judie. Effecttivenness of Birthball Usage During Labour on Pain and Child Birth Experience Among Primi Parturient Mothers : A Randomised interventional study. IJSR - international journal of scientific research. 2014.

Winny SC, Sze-wing, dan Wan-hon LI . The Birth Ball Experience: Outcome Evaluation of the Intrapartum Use of birth ball. HKJGOM, 2011.

Error! Reference source not found. 